\title{
The other side of fieldwork: experiences and challenges of conducting research in the border area of Rwanda/eastern
}

\section{Congo}

By Larissa R. Begley (University of Sussex)

This paper will explore various experiences and challenges that have occurred during my ongoing fieldwork. Beginning in March 2008 and continuing until October, fieldwork for this research has taken place in the border region of Rwanda and the eastern Democratic Republic of the Congo (DRC), specifically in the cities of Cyangugu and Gisenyi, Rwanda, and to a lesser extent Goma and Bukavu, DRC. Most anthropologists in the field will experience feelings of isolation and loneliness. However, the current conditions of this region, which remains a conflict zone under tight government control, add another dimension. This has contributed to further feelings of isolation, frustration, fear, distrust, insecurity, and with no clear way to seek support for both the informants and the anthropologist. This paper will address these challenges and the ways that they impact on the research process itself, as well as the effects they have on the anthropologist.

\section{Introduction: studying "lived experiences"}

As students of anthropology, we spend most of our academic lives learning about the "field" as one of the most crucial aspects of anthropology. As anthropology is concerned with the interactions and relationships of people, we undertake fieldwork to understand the complexity of social life. This focus on long-term fieldwork is what separates anthropology from other disciplines and was a major factor in my decision to become an anthropologist. Anthropologists play an important part in the narratives they construct. However, as Green (1995:107) acknowledges, "Anthropologists [...] have traditionally approached the study of conflict, war, and human aggression from a distance, ignoring the harsh realities of people's lives." When fieldwork is being conducted in a region where war, fear and everyday violence is a fact of life, it becomes part of the anthropologist's life. Recently, anthropologists (see Green 1995, Nordstrom 1995, 1997, Sanford 2003, Taussig 2003) have approached the study of conflict and violence by focusing on what Nordstrom (1995:139) refers to as the "lived experiences" of people within these areas. Thus, anthropologists have chosen to embed themselves within the realities of those they study rather than distancing themselves from them.

Undertaking such a task, however, has many consequences for both researchers and participants. I argue that when problems arise in the field or afterwards, many anthropologists are often unprepared and unable to receive adequate support. Thus, it becomes necessary to emphasise the need for awareness and sympathy for the emotional, psychological, and physical stress that we go through while in the field. For doctoral students who return from the field it is especially critical to have open 
communication, understanding and support from supervisors, departments, the academic institution, and from peers. This is especially vital for anthropologists who conduct research where violence, fear, and poverty are predominant features in the lives of those we study. I wrote part of this paper while on fieldwork, where the government had tight control over every aspect of peoples' lives, and the rest upon my return to the UK. This has provided me with a unique perspective on the issue of receiving support in the field. Using my own personal experiences, I wish to highlight the importance of receiving adequate "support" in the field and upon return. Furthermore, these experiences and the trauma associated with it not only impacted me on a personal level, but also became a crucial component of my dissertation. In what follows, I will argue that when I entered the domain of "lived experiences" of my participants, fear and suspicion became very much a part of my everyday life. It played a predominant role in constructing and shaping the research and writing process. As Nordstrom (1995:3) argues,

This emphasis on how people come to grips with life under siege, on the experience, practice, and everydayness of violence, makes attention to fieldwork conditions necessary. The emotional intensity of the events and people studied, the political stakes that surround research on violence, and the haphazard circumstances under which fieldwork is being conducted entwine fieldwork and ethnography. These tensions weave their way through the whole of the anthropological endeavor - coloring the lives and perspectives of the researchers and those they study alike.

To further illustrate Nordstrom's argument, I have chosen to include a few unedited excerpts from my field notes. In doing so, I wish to draw attention to the fact that it was only with the support of various people and institutions that I was able to address my own fear and trauma and begin to process the value and connection these experiences have to the narratives I collected. In referring to "support", I wish to include an entire spectrum that encompasses academic guidance (i.e. supervisors, departments, colleagues, and experts), as well as emotional support (i.e. friends, family, and psychologists, etc.).

\section{Research in a conflict zone}

I conducted six and half months of fieldwork in the Kivu border region of Rwanda and the eastern Democratic Republic of the Congo (DRC), from March to October 2008. When I entered the field in late March 2008, the region was relatively peaceful. Rwanda as a whole has enjoyed (at least on a superficial level) political stability and peace for a decade. I quickly learned that this "peace" and "political stability" was the result of strong military control and presence in the everyday lives of Rwandans. In late August, the situation in eastern Congo deteriorated and the relationship between Rwanda and Congo became further strained. In retaliation against the actions of Congolese Tutsi rebel leader Laurent Nkunda, several Rwandan students were killed and Rwandans in Congo were beaten and accused of being spies for Nkunda. All-out war seemed inevitable. This situation had a direct impact on my ability to conduct research in Rwanda. Due to the rising insecurity in eastern Congo, the Rwandan government started deploying more soldiers and spies to this region. These spies were naturally suspicious of foreigners. The situation became so dangerous that my presence was enough to put my informants/participants' security in jeopardy. Given these circumstances, I decided to leave the field two months early. 
From field notes, 2 October 2008

I was on the sofa typing up my notes, when Joseph, my translator called. He told me that a lot of bad things happened. One of my key participants, David had contacted Joseph. David told Joseph that some government officials had interrogated a few of my participants. They told these officials what was discussed during our interviews. I was too terrified to ask Joseph for any particular details. Joseph simply told me to "leave the country as soon as you can and do not come back to this town". I hung up the phone and I learned what it means to be truly fearful. I paced up and down the house trying to figure out what I should do. I considered going to Goma to email my supervisors. However, with the rising tension and being on the brink of all-out war, I couldn't risk the Rwandan border officials asking me questions about why I keep going to Goma. I feel helpless. I tried to write a coded email to my supervisors. We have been using weather terms, such as it's getting really hot here, for things are not going well and there have been some problems. But how do I convey Rwanda's getting ready to invade Congo, Congo is on the brink of all-out war, and the Rwandan government knows everything I learned and is interrogating my participants, using weather terms? There's no weather term that can adequately communicate that people could be killed for what they told me and I have no way to protect them. In the end I stated that there was a huge storm and another one coming from across the lake. It was so hot here that no one could have predicted how hot it was really going to be. I sent the email and then I broke down. Six months of stress, panic, and fear had finally caused me to have a complete breakdown. This is too much. I can't take it anymore and there's no sense for me to stay here. I feel completely alone and isolated. I'm completely terrified that people are going to be thrown in jail for genocide ideology or even killed for what they told me. And there's no one I can talk to. There's no one to tell me what I should do, because the government is watching my emails and after this incident I have no doubt that they are. I have to leave. It's three in the morning and I can't sleep. I can't sit still nor can I focus. I just need to get out of here.

For most anthropologists, fieldwork is an isolating and lonely experience. Separated from friends, family and from basic comforts, the cultural differences and being the "Other" all contribute to a frustrating and stressful situation. With modern-day technology, email and internet access make staying in contact with the outside world a bit easier when connection is available. Facebook and Skype provided me with regular communication with friends and family at a time when I needed them the most. However, I could not tell anyone why I was upset or what was occurring. Contents of my day had to remain vague due to the politically controlled environment of Rwanda. There were points in time when I could feel myself becoming overwhelmed by my own research, yet unable to express any of it. Growing up in a free society that guarantees freedom of speech gives one an almost "natural" sense of security. However, in parts of the world where so much rests on the ability to keep quiet, silence can be one of the hardest things to learn in the field. While the above passage highlights how the entire research experience was plagued with fear, it is important to consider the role fear played in setting the research context.

\section{Fear}

Among many Tutsi, pro-Rwandan Patriotic Front (RPF), and Congolese there is the common belief that Rwanda is stable and secure. However, my own experiences 
suggest that this is not the entire picture and that there is a fine line between "security" and "government control". Experiences such as those I had with the Imam and Robert (see below) as well as the intimidation of my participants provided me with a deeper insight into the everyday realities of fear that Rwandans must cope with. Furthermore, as long as I was in Rwanda, I had no way to seek immediate help from my supervisors or from anyone. The constant mistrust, the feeling of always being watched, having no friends and no one who understood the situation to offer advice or support, and living in constant fear, all made my fieldwork isolating and nerveracking.

To help ease the situation, I adopted strategies that Rwandans employ to avoid suspicion. For example, many Rwandans have joined the Rwandan Patriotic Front (RPF) in order to avoid suspicion and to prevent problems with soldiers. The RPF was the Rwandan Tutsi rebel army living in exile in Uganda. In 1990, they invaded Rwanda and began a civil war with Habyarimana's regime. The RPF took control of the country after the genocide and is still the dominant political party. When I discovered that the government had spies following me, I began to wear a hat with the logo of the RPF on it. I also sought to interview prominent RPF officials and businessmen, asking relatively harmless questions.

However, as Green (1995:228) contends about her research in Guatemala: "Fear became the metanarrative of my research and experiences." Fear became an overarching and recurring theme throughout mine.

From field notes, 29 July 2008

I was having breakfast at a restaurant that I usually went to. I met my translator and we left to go meet an Imam. Nothing seems out of place or wrong, just a normal day. There are plenty of street kids around, nothing unusual. We arrive and begin the interview. The Imam destroys every stereotypical imagine of what an Imam is portrayed to look like. He's wearing sunglasses, despite the complete lack of light in the house. He has a plain blue t-shirt on and baggy cloth pants. He looks straight out of a 1980s R\&B music group. His demeanour is laidback and relaxed. The Imam is discussing how Muslims have contributed to the reconciliation process in post-genocide Rwanda. The purple and green lights from his phone begin to flash and I get distracted. He answers it and at first remains sitting on the sofa, than leaves out the front door. He returns after a few minutes and the interview continues. As soon as we are away from the Imam, Joseph informs me: "We are being watched." My heart falls into my stomach and I ask how he knows. "I overheard the Imam's conversation on the phone. The person on the phone was the District Chairman of the RPF. He says that there is a white person at your house. What does she want? What is she doing there?" "What did the Imam say?" I asked almost desperately. "He said that you were here doing research on Islam and that you were on 'our side'." Somehow those words do not ease the wave of panic that has come over me.

The next day I am told exactly what happened and was no longer allowed to eat breakfast at my usual place. One of my informants told Joseph that he watched the waiter from the restaurant hire a couple of street kids to follow us. The street kids reported to another man on the street who than contacted the Chairman of the RPF. Furthermore, it was not just one, but five different men who have been following our movements. I was terrified because of what could happen to my participants and translators. They have no embassy to run to if something were to happen. It was my responsibility to protect them, 
which up until that moment I thought I had. However, at this moment all these security measures seem far from adequate. My entire research project seems careless and reckless.

This week left me emotionally drained and physically ill. Nothing in all the ethnographic methodology courses or in eight years of anthropology prepared me for these situations. I remember exercises about protecting confidentiality. They seem so trivial when spies are everywhere hiring street kids to follow you. I was further isolated because I could not seek immediate support or advice. Rumours that the Rwandan government tapped phones and emails were prevalent, and many had stories that gave these rumors legitimacy. I have no evidence to suggest the government actually did tap my emails or phone calls. The warnings from my supervisors before I left and my translators forced me to work under the assumption that the government would.

There was one incident in which I received an email from a person whom I had never met before stating he was sending me documents on behalf of a Rwandan official. The email contained documents about the atrocities committed by the RPF during the civil war, genocide and afterwards. This made me extremely nervous in case the government did decide to check my emails. I emailed this person after my return to the UK, to see if he could tell me why and who told him to send me that information. He replied: "We learnt from Kigali officials that a young and naive young woman was making research on Rwanda tragedy. We were asked to provide you with 'good' information. That means, we were asked to repeat Kagame and his fellows' speech on what happened and what is happening in Rwanda and in the Great Lakes area. We consider Kagame and his sponsors (USA, UK, some West companies) as the main actors of Central Africa tragedy" (received 5 November 2008).

After my visit to the Imam and learning that I was being watched, I was so desperate for advice that I went across the border to Goma, where I thought I could send my supervisors an email safely and away from the prying eyes of the RPF. I asked a Congolese friend if the Congolese government spies on people's emails. "No, the government in Rwanda will, but not here in Congo. In Congo the government has much bigger problems to worry about." A few weeks later, going to Goma to send emails would no longer be an option due to the rising tension in the region and between the two countries, thus taking away my sole safety net.

Limitations such as these are hard enough, but it became even more difficult when I realized what was at stake. The safety of informants is a serious ethical problem that anthropologists must be aware of. There was the fear that no matter how hard I tried and all the precautions I took to protect my participants - such as fake names, changing the locations of the interviews, coding field notes - there was always a risk. Given all these risks and consequences, which those I talked with were well aware of, it was surprising that some people were willing to discuss topics considered taboo in Rwandan society. Furthermore, they thanked me for giving them an opportunity to tell their story.

Das's (1990) research in India and Nordstrom's (1997) in Mozambique found that victims had a real need and desire to communicate their experiences. Nordstrom (1997:79) contends: "Words serve to give voice to the unspeakable [...] Words serve to mourn the dead and create meaning in a new and brittle world." Additionally, people share their experiences to challenge the political and social institutions that have constructed a "reality" that does not fit into and misrepresents the lived 
experiences of the victims (ibid). As Suárez-Orozco (1992:367) has noted, "testimony is a ritual of both healing and condemnation of injustice - the concept of testimony contains both connotations of something subjective and private and something objective, judicial and political".

While focusing on the real need participants have to have their testimony heard, I will use the case of Robert to bring attention to the serious consequences of conducting research that goes against an authoritarian government's policy. In face of these consequences, I was left with no safe way to receive advice or guidance. There was little that prepared me to handle the situation and what should be done.

\section{Robert}

Robert had been in the military with Juvenal Habyarimana before Habyarimana became president in 1973. It was Habyarimana's assassination that would ignite the 1994 genocide. According to Robert, his neighbour's brother blamed him for the death of the neighbour during this period. During the genocide, the Interahamwe (the Hutu militia that carried out the genocide) detained the neighbour at a roadblock. Robert went to the district office and claimed this man as his brother. He was able to obtain an identity card that stated the neighbour was Hutu, paying a fairly large sum of money for the documents. When the neighbour was released he fled to the Congo; however, the Interahamwe killed the neighbour at the border. The neighbour's brother believed that Robert purposefully sent his brother to be killed.

Robert fled to the Congo like millions of Rwandans who feared the retribution of the newly installed government (the RPF). Robert returned to Rwanda two years later, only to be arrested two days after his return on genocide charges. He spent five years in prison without a trial before finally being found innocent by both the formal courts and the traditional courts, called gacaca, which have been set up to prosecute genocide crimes. While in the Congo, his neighbour's brother occupied Robert's house. When the neighbour's family was forced to vacate the house, they took all the doors and windows from it, leaving Robert with nothing. During our interviews, Robert spoke at great length about his time in prison where he was beaten and forced to live in inhumane conditions. He also praised Habyarimana, and spoke of his discontent with his neighbours and the government. As a result of the past, the current relationship between Robert and his neighbours remains very tense. Surrounded by Tutsi, Robert often feels that they are trying to push him out of his house and off his property.

I had been away from Cyangugu for about three weeks when I returned and met with my translators. Joseph told me he had seen Robert go by in a police car and after enquiring about him, all they knew was that he had been arrested for genocide ideology. There is no way to describe the absolute panic I felt. Was he arrested because of me? Did someone find out? What the hell did I do? How am I going to get this man out of this situation or would I just make things worse? I did not sleep at all for several nights. I was once again reminded of the responsibility that I have to my participants and that I had possibly failed Robert. I was faced with a situation that I had no idea how to deal with and with no way to seek help or advice from others.

In the end, Robert's arrest had nothing to do with our interviews. He had another disagreement with his neighbours about the location of his granary. The police were called because his neighbour's brother stated that Robert had insulted them (this is a 
way of inferring that Robert made a reference to a person's ethnic identity, all of which Robert denied). Robert had been imprisoned for three days when his brother-inlaw arrived to help him. Robert was told to keep quiet because if he did not he would be in a lot more trouble. The police commissioner told him to pay the fee, go home and destroy the granary and to keep quiet. Robert destroyed the granary, but was angry over the situation. Three of his neighbours also had granaries identical to his and in relatively similar locations. However, they were allowed to keep theirs. In his opinion, the only difference between the granaries was that the others belonged to Tutsi.

Taussig (2003:12) maintains, "Knowing what not to know becomes not only an art of survival but the basis of social reality". I would argue that Taussig's statement can also be applied to knowing what can and cannot be said or done. This is particularly true in the case of Robert, since his statements are the equivalent of "genocide ideology" in the context of Rwandan politics. "Genocide ideology" is a blanket term used by the government to describe speech, beliefs and actions that "lead to ethnic divisionism". The Rwandan constitution fails to provide a definitive definition of "genocide ideology", whereas the 2002 law against divisionism or sectarism stated that "the practice of sectarism is a crime committed by any oral or written expression or any act of division that could generate conflicts among the population or cause disputes" (Law no. 47/2001, article 3). According to Human Rights Watch (2009:102) "the current definition is vague, requires no link to any genocidal act, and prohibits speech protected by international convention". Furthermore, Human Rights Watch contends that the Rwandan government is using "genocide ideology" to silence dissent (Human Rights Watch 2009:102). Many of my participants agreed, describing "genocide ideology" as a tool used by the government to maintain their political hold over the population and to discriminate against Hutu. Many of those I talked to risk going to prison for "genocide ideology" for what they revealed. The extent of the situation is well illustrated in a Human Rights Watch World Report (2007:143) which says of the Rwandan government:

In a continuing campaign against "divisionism" and "genocidal ideology", authorities compiled a list of hundreds of persons suspected of such ideas. Banned by the constitution, "divisionism" is vaguely and broadly defined in a 2001 law. A priest was sentenced to 12 years' imprisonment in September 2006 for minimizing the genocide. In a sermon he had suggested it was wrong to call persons who participated in genocide "dogs". During the trial, the prosecutor allegedly said that those convicted of genocide were not human and should properly be called "dogs".

Joseph described a similar sentiment after an interview with Robert: "Anything can be considered genocide ideology. When Robert called the genocide a 'war', that is enough to get him arrested." Despite the abstract definition of the concept, the law is quite clear on the punishment for such acts and ideas. According to the law, anyone found guilty of killing a person based on genocide ideology will be given life in prison. For a first time offence, a person will be given a sentence of 10 to 25 years in prison and a fine ranging from roughly 130 to 1000 pounds. A person found guilty for a second time will be given a life sentence. Children less than 12 years of age will be imprisoned in a rehabilitation centre for up to 12 months (Rwanda News Agency 2008).

This case raises many ethical questions. How are anthropologists and social researchers supposed to handle such a situation? Do we give up our research or 
change the focus to something less politically charged? These were questions I had to figure out without guidance or advice. Furthermore, the ethical considerations must be weighed against the need participants have to have a testimony be heard, particularly when there is a disjunction between the "reality" the government is portraying and the "reality" they have experienced. I argue that the act of Robert discussing his arrest and mistreatment while in police custody was itself a challenge to the political and social institutions that demand absolute silence. At the end of my last interview with Robert, I asked if there was anything he wanted to add. "You go and tell them what life is really like here. Tell them that the government is lying. Rwanda is not democratic and there is no reconciliation. Thank you for listening to our side."

\section{Receiving support post-fieldwork}

These experiences not only stayed with me during the time in the field, but also continued to impact me upon my return to the UK. In fact, the hardest lesson I learned from the field was that the field does not leave just because you leave the field. In fact, I have found that returning home has been just as difficult as fieldwork. It has come to my attention that many $\mathrm{PhD}$ anthropology students have similar feelings and experiences regarding the field. Once home, they still feel isolated, frustrated, and disillusioned by their experiences. I suffered from this as well as feeling like I had failed as an anthropologist. In the field, I was never able to engage in the everyday activities of my participants due to the suspicion this would cause. Participation raised suspicion. To have a white woman be seen going into the home of a poor Rwandan would attract the attention of spies and soldiers, putting people's security at risk. Asking the wrong question to the wrong person could have resulted in horrific consequences for my participants such as imprisonment, disappearing, or death, while I would face expulsion and possible imprisonment. While many researchers who study Rwanda experience few problems, my fear of the authorities and the RPF was related to the fact that I was guilty. I had collected information that went against government policies and stances on reconciliation, history, the elections, and the Congo Wars. My participants and I would have been considered to be genocidaires or to be spreading lies if the government found out about our discussions. While it is true that millions of people live with fear and violence every day, this does not mean the impact is felt any less. As Green argues,

While it is true that with repetitiveness and familiarity people learn to accommodate themselves to terror and fear, low-intensity panic remains in the shadow of waking consciousness. One cannot live in a constant state of alertness, and so the chaos one feels becomes infused throughout the body. It surfaces frequently in dreams and chronic illness. (Green 1995:109)

\section{From field notes, 13 October 2008}

I've been back in the UK for three days. I can't sleep and when I do I'm having nightmares about my experiences. The first night, I dreamt that I was still in Gisenyi, when Rwanda and Uganda soldiers started to attack Goma. I just remember trying to jump a fence but I was trapped. Even in my dream I could sense the impending war. Even then I was still more terrified of the Rwandan soldiers than anything else. Last night I was plagued with two of them, I forgot the second one. My friend who visited me while I was doing my fieldwork had come back and we went to Cyangugu. I had forgotten that I 
wasn't supposed to go back. I remembered I wasn't supposed to be there when we approached a roadblock. A soldier pointed his gun to my head and shot me. After each nightmare, I feel the familiar weight of pressure, stress, and panic, when I wake up. It takes me a while to realize that I'm safe. Yesterday, I went for a walk, I panicked when a man came running past me. My entire body tensed and I moved out of his way clinging to my bag. That happened about four or five times in a two-hour walk through the city. I kept looking around, still feeling nervous and anxious.

I looked at FDLR's website and it's strange. I still feel like someone is watching me, that at any moment the RPF soldiers are going to show up and arrest me for looking at this website. Every time someone walks through the door, I shut my laptop. I have finally broken myself from the habit of whispering when I say Hutu or Tutsi and constantly looking around to see who is listening to my conversation. It had almost become a natural reaction.

(The Democratic Forces for the Liberation of Rwanda, FDLR, is the Rwandan Hutu militia made up of the Interahamwe, ex-government forces, genocidaires and those who grew up in exile after 1994.)

My fieldwork experience is a textbook example of Green's argument. While in the field the stress caused my chronic fibromyalgia to become intolerable to the point that I could not get out of bed for days. I am still feeling the effects of this stress when I am suffering from migraines, nightmares, chronic fatigue, sleeplessness, and overall pain.

It has been extremely difficult for me to read my field notes or to discuss my experiences. Writing this paper has been extremely taxing because I do not want to relive my own fear. It is extremely frustrating, because you think (as well as those around you) that you should return to your normal self, but those experiences follow you. For those who conduct research in areas where violence is part of everyday life, the adjustment is more than just cultural shock. For me, returning back to the UK was the first time I was allowed to talk freely about my experiences and really come to terms with everything I had experienced. I found myself wanting to forget everything. However, since my degree depended on this information, I could not simply do so;,however, I was still unable to start analysing data or writing. I sought psychological support but was forced to wait over two months for an appointment with a psychologist. As a result, I was not able to do much work, and fell behind on my research.

My biggest problem is the guilt and fear for what could happen to my participants and translators. How do we cope with these types of consequences of our research? For most of us, we can physically leave the field behind us once our research is done. We get to physically escape the everyday violence we see and go back to our sheltered lives. We only have to bear the small glimpse of what our participants go through every day for their entire lives for a short period. However, at the same time, we are forced to relive and recount that small glimpse every time we read and examine our field journals, every time we try to write a chapter or a paper. Those experiences do not leave simply because we do. As anthropologists, we are part of the narrative we create. Our fieldwork does not exist detached from our own emotions and our lives. We impact on those we study and they impact on us.

It is because of this dialectical relationship we have with the "field" that we must recognize the impact that fieldwork can have emotionally, psychologically and 
physically on us. In the case of dangerous research contexts, Nordstrom adequately describes the impact that the very nature of the "data" we collect can have. She states:

It is misleading, however, to focus exclusively on the physicality of bodies as the repository of violence. When I am among people who have not been near the brute force of war, I am often asked, "What was it like? Did you see many dead bodies?" [...] Even if I were to answer the question, which I never do, it would not be the ruined bodies themselves that I have seen that summarize the agonizing truths of war for me, but the stories behind the bodies. (Nordstrom 1995:141)

I have seen the preserved dead bodies of genocide victims in Rwanda. However, what stays with me are the stories of the genocide victims and the testimonies of those who were chased and massacred in the Congolese forests by the RPF, or, for instance, Robert's experience of the horrific conditions and treatment of prisoners. It is this repetitiveness and familiarity of fear, which has become institutionalised, and the stories I heard that haunt me. I am traumatised by my own research and very few people are able to give me advice about how to deal with this situation.

Many aspects of a doctoral degree are stressful and students must endure extreme amounts of pressure. However, the process becomes its own nightmare when the student cannot remove the sense of fear that has remained with them. These are issues that must first be recognized and secondly addressed by anthropology departments and their members. I believe that it is imperative for anthropologists to begin by discussing and sharing their experiences, by including them in anthropological literature and methodology courses. By preparing students for the widest range of experiences in the field, it will provide them with more useful and practical tools for coping with fieldwork.

\section{References}

Das, V. 1990. Our work to cry: Your work to listen. In Mirrors of violence: Communities, riots, and survivors in South Asia, ed. V. Das, 345-98. Delhi: Oxford University Press.

Green, L. 1995. Living in a state of fear. In Fieldwork under fire, eds. C. Nordstrom and C.G.M. Robben, 105-28. Berkeley: University of California Press.

Human Rights Watch. 2007. Human Rights Watch World Report. 11 January.

-------. 2009. Human Rights Watch World Report. 14 January.

Nordstrom, C. 1995. War on the front lines. In Fieldwork under fire, eds. C. Nordstrom and C.G.M. Robben, 129-54. Berkeley: University of California Press.

-------. 1997. A different kind of war story. Philadelphia: University of Pennsylvania Press.

Rwanda News Agency. 2008. Rwanda: Parliament passes tough law against genocide revisionism. 8 February.

Sanford, V. 2003. Buried secrets: Truth and human rights in Guatemala. New York: Palgrave Macmillan.

Suárez-Orozco, M. 1992. A grammar of terror: Psycho-cultural responses to state terrorism in Dirty War and post-Dirty War Argentina. In The path to 
domination, resistance and terror, eds. C. Nordstrom and J. Martin, 219-59. Berkeley: University of California Press.

Taussig, M. 2003. Law in a lawless land: Diary of Limpieza in Colombia. Chicago: University of Chicago Press.

\section{About the author}

Larissa Begley is currently writing her PhD thesis at the University of Sussex, on how people and the nation-state engage with public and hidden transcripts of various social processes in post-genocide Rwanda. Her research interests include social identities, state control and terror, conflict, genocide ideology, fear, international borders and refugees. She can be contacted at l.begley@sussex.ac.uk. 